\title{
Acidiphilium cryptum gen. nov., sp. nov., Heterotrophic Bacterium From Acidic Mineral Environments
}

\author{
ARTHUR P. HARRISON, JR. \\ Division of Biological Sciences, University of Missouri, Columbia, Missouri 65211
}

\begin{abstract}
Acidiphilium gen. nov. is comprised of gram-negative, aerobic, mesophilic, rodshaped bacteria that grow in lean organic media between $\mathrm{pH} 1.9$ and 5.9 but not at $\mathrm{pH}$ 6.1. Small amounts of organic substrates are required for growth, but high concentrations inhibit growth, especially the organic digests used in conventional bacteriological media. Sodium acetate is strongly inhibitory at a concentration of $0.01 \%$. Endospores are not formed, and some strains are motile by means of one polar flagellum or two lateral flagella. The guanine-plus-cytosine content of the deoxyribonucleic acid varies between 68 and $70 \mathrm{~mol} \%$. Some catalase is formed, but the oxidase reaction is very weak or absent. This genus differs from Pseudomonas, Chromobacterium, Flavobacterium, and other soil heterotrophs by its requirement for a high concentration of hydrogen ions and its sensitivity to many organic substrates. It differs from Pseudomonas also by its lack of a strong oxidase reaction and especially by its inhibition by acetate. It is easily distinguished from acidophilic thiobacilli by its inability to utilize sulfur and ferrous iron as sources of energy and by the high guanine-plus-cytosine content of deoxyribonucleic acid. The type species is Acidiphilium cryptum, and the type strain of this species is strain Lhet2 $(=$ ATCC 33463$)$.
\end{abstract}

Heterotrophic, mesophilic bacteria with requirements for high acidity have been isolated from allegedly pure cultures of Thiobacillus ferrooxidans (6). These heterotrophs cannot use elemental sulfur or ferrous iron as a source of energy; instead, they utilize organic matter formed by the autotroph $T$. ferrooxidans (B. W. Jarvis, M.S. thesis, University of Missouri, Columbia, 1979). Heterotrophic bacteria identical to the organisms isolated from $T$. ferrooxidans cultures were isolated on very dilute Trypticase soy glucose medium at $\mathrm{pH} 2$ directly from acidic coal refuse in Missouri. Bacteria phenotypically similar to these organisms have also been isolated from coal mine water in Pennsylvania (P. L. Wichlacz, M.S. thesis, Pennsylvania State University, University Park, 1980) and from mine drainage elsewhere (10). Other isolations of these bacteria have been described previously (6). In this report I describe these acidophilic heterotrophs in greater detail and propose names for them.

\section{MATERIALS AND METHODS}

Media. The bacteria were cultivated in a medium containing the following (per liter): $\left(\mathrm{NH}_{4}\right)_{2} \mathrm{SO}_{4}, 2 \mathrm{~g}$; $\mathrm{KCl}, 0.1 \mathrm{~g} ; \mathrm{K}_{2} \mathrm{HPO}_{4}, 0.5 \mathrm{~g} ; \mathrm{MgSO}_{4} \cdot 7 \mathrm{H}_{2} \mathrm{O}, 0.5 \mathrm{~g}$; dehydrated Trypticase soy broth (BBL Microbiology Systems, Cockeysville, Md.), $0.1 \mathrm{~g}$; and glucose, $1 \mathrm{~g}$. The $\mathrm{pH}$ was adjusted to 3 with $1 \mathrm{~N} \mathrm{H}_{2} \mathrm{SO}_{4}$. The glucose was autoclaved separately as a $10 \%$ solution, and after cooling a suitable amount was added aseptically to the other autoclaved ingredients ( $\mathrm{pH}$ 3). This medium without the organic ingredients was designated basal salts medium; when it contained Trypticase soy and glucose, it was designated TS-glucose medium. When solid media were desired, the liquid media were gelled with agar $(12 \mathrm{~g} /$ liter). The agar and glucose (double strength) and the other ingredients $(\mathrm{pH} 3$; double strength) were autoclaved separately at $15 \mathrm{lb} / \mathrm{in}^{2}$ for $15 \mathrm{~min}$ and then mixed after cooling. In growth studies with different organic substrates, the organic compounds were sterilized separately (autoclaved or filtered as necessary in each case) and then added aspectically to the basal salts medium. When the substrate being tested would have affected the $\mathrm{pH}$, the appropriate correction was made; the $\mathrm{pH}$ was monitored in these experiments to ensure that it did not influence the results.

Isolation of bacteria, maintenance of stock cultures, and test strains used. Several strains of acidophilic heterotrophs were isolated in enrichment cultures by using $100-\mathrm{ml}$ quantities of TS-glucose liquid medium with the $\mathrm{pH}$ adjusted to 2 in 0.5-liter Erlenmeyer flasks. About $1 \mathrm{~g}$ of soil was added to each flask, and the flask was incubated at $28^{\circ} \mathrm{C}$ on a rotary shaker. After several days, material from the flask was streaked onto TS-glucose agar, and individual colonies were selected. After preliminary tests to ensure purity, stock cultures were prepared on TS-glucose agar slants, which were stored in a refrigerator; transfers were made monthly. Other strains were acquired from allegedly pure cultures of $T$. ferrooxidans (6) and from an artificial coal spoil (5). I performed preliminary tests to confirm that these isolates were strict heterotrophs (i.e., that they were not able to utilize either sulfur or ferrous iron as an energy source), that they 
grew between $\mathrm{pH} 1.9$ and 5.9 but not at $\mathrm{pH}$ 6.1, and that they did not grow on conventional peptone media at low $\mathrm{pH}$ values. From this collection of isolates, I selected seven representative strains for this study (Table 1).

Diagnostic tests. Catalase was detected by using a $3 \%$ hydrogen peroxide solution that was added directly to TS-glucose agar cultures. Staphylococcus aureus and Streptococcus faecalis served as positive and negative controls, respectively. Growth on TSglucose agar was also used for the oxidase test, which was performed by the para-aminodimethylaniline disk method. Pseudomonas fluorescens and Neisseria strains served as positive controls, and Escherichia coli and Enterobacter aerogenes served as negative controls. Growth, pH, and temperature studies were performed on the same medium. Heat tolerance was determined by using growth from a 1-week-old TSglucose agar culture suspended at a high density $(5 \times$ $10^{8}$ cells per ml) in liquid TS-glucose medium in small test tubes $\left(11\right.$ by $100 \mathrm{~mm}$ ) in a $67^{\circ} \mathrm{C}$ water bath. Glucose utilization was measured by the phenol-sulfuric acid colorimetric method of sugar analysis (3). Cell numbers were assayed by plating diluted samples onto TS-glucose agar and were also determined by microscopic counts, using phase-contrast microscopy and a Petroff-Hausser bacterial counting chamber. Antibiotic susceptibilities were determined by the disk method on TS-glucose agar plates.

The type of flagellation was determined by the Leifson staining method (1) and also by electron microscopy. Two drops of a thick cell suspension were mixed with 4 drops of $2 \%$ phosphotungstic acid and 1 drop of $0.1 \%$ bovine serum albumin. This mixture was deposited on carbon-coated copper grids (300 mesh), and the preparation was examined with an RCA model EMU-3F transmission electron microscope.

Examination of DNA. The bacteria were cultivated, the deoxyribonucleic acid (DNA) was prepared, and the DNA homology study was performed as described previously (6). Purified DNA was diluted in $0.1 \times \mathrm{SSC}(1 \times \mathrm{SSC}$ is $0.15 \mathrm{M} \mathrm{NaCl}$ plus $0.015 \mathrm{M}$ sodium citrate, $\mathrm{pH}$ 7.0). The guanine-plus-cytosine $(\mathrm{G}+\mathrm{C})$

TABLE 1. Sources and habitats of the acidophilic heterotrophic bacteria studied

\begin{tabular}{|c|c|c|}
\hline Strain & Source and/or habitat & Reference \\
\hline Lhet2 & $\begin{array}{l}\text { From a culture of } T \text {. ferrooxidans; } \\
\text { coal mine water from Pennsyl- } \\
\text { vania }\end{array}$ & \\
\hline 13598het & $\begin{array}{l}\text { From } T \text {. ferrooxidans ATCC } \\
\text { 13598; copper mine dump ef- } \\
\text { fluent, Bingham Canyon, Utah }\end{array}$ & \\
\hline$m-5$ & $\begin{array}{l}\text { Coal strip mine refuse, Calloway } \\
\text { County, Mo. }\end{array}$ & 5 \\
\hline$m-3$ & $\begin{array}{l}\text { Coal strip mine refuse, Calloway } \\
\text { County, Mo. }\end{array}$ & 5 \\
\hline Dhet1 & $\begin{array}{l}\text { Coal strip mine refuse, Randolph } \\
\text { County, Mo. }\end{array}$ & \\
\hline Dhet2 & $\begin{array}{l}\text { Coal strip mine refuse, Randolph } \\
\text { County, Mo. }\end{array}$ & \\
\hline$K G-4 p$ & $\begin{array}{l}\text { Derived from KG- } 4 \text {; isolated by } \\
\text { Shafia and Wilkinson from a } \\
\text { culture of } T \text {. ferrooxidans; cop- } \\
\text { per mine effluent, Utah }\end{array}$ & 13 \\
\hline
\end{tabular}

content of the DNA was determined by the DNA melting point method in $0.1 \times \mathrm{SSC}$; a Gilford thermoprogrammer, a multiple-sample recorder, and a Beckman model DU spectrophotometer were used. To determine the melting point, the diluted DNA was dialyzed together with DNA from $E$. coli strain B as a reference. The best estimate for the $\mathrm{G}+\mathrm{C}$ content of $E$. coli B DNA is $51.0 \pm 0.25 \mathrm{~mol} \%$ (12; M. Mandel, personal communication). Using this value and the experimental melting point for $E$. coli B DNA, the results were normalized to $E$. coli B DNA by using the equation of Mandel and Marmur (9).

\section{RESULTS}

Morphology. Living cells of these heterotrophic bacteria grown in TS-glucose liquid medium were rods which measured 0.3 to 0.4 by 0.6 to $0.8 \mu \mathrm{m}$. The cells of strains 13598 het and KG$4 p$ tended to be shorter than the cells of the other strains. When they were grown in liquid Trypticase soy-citrate medium (TS-glucose medium but with $0.1 \%$ sodium citrate in place of glucose), the cells of all strains were longer than when they were grown in TS-glucose medium. For example, strain Lhet 2 was approximately 1.3 $\mu \mathrm{m}$ long in Trypticase soy-citrate medium. Be-

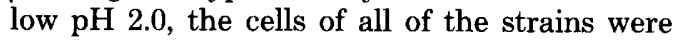
shorter. Strains $m-3$ and $m-5$ appeared to be cocci and formed short chains, thus resembling streptococci. All strains were gram negative, and all strains except 13598het and KG-4p were motile; none formed endospores. Electron microscopy revealed that one strain, strain Lhet2, had numerous pili.

Flagellation. An examination of strain Lhet2 by electron microscopy demonstrated that most of the flagellated cells had two flagella and that these flagella were attached laterally (Fig. 1A and $\mathrm{B}$ ). However, some cells (the longer cells in the cultures) had a single polar flagellum (Fig. 1C). The strain shown in Fig. 1 was also examined with an oil immersion lens after the cells were stained with Leifson flagellum stain. Under an optical microscope, all of the flagellated cells appeared to be monotrichous. To prepare the smear, a drop of cell suspension was allowed to flow down the surface of a glass slide as the slide was tilted. The current created by this procedure or the movement of the cells themselves as they swam from the drying edge of the smear apparently caused the two lateral flagella to lie close together or to become entangled, so that when they were coated with mordant and stain, they appeared to be one flagellum. Moreover, the flagella were so thickened and the cells were so small under the optical microscope that it was not possible to observe whether the flagellum was polar or lateral. (Proteus and Escherichia cultures served as peritrichous controls, and a 


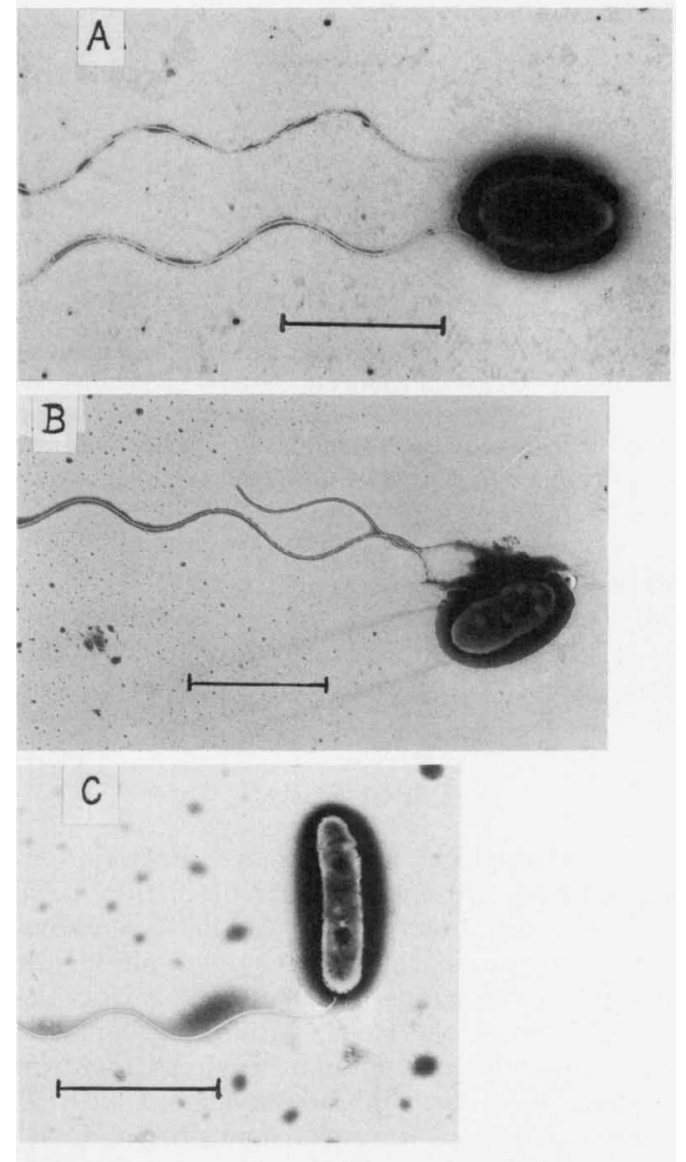

FIG. 1. Electron micrographs of the acidophilic heterotroph strain Lhet2. Bars $=1 \mu \mathrm{m}$.

Pseudomonas culture served as a monotrichous control with the Leifson stain.) Motility was examined by phase-contrast microscopy. Strain Lhet2 in TS-glucose liquid medium was actively motile. Moreover, the cells were sticky. When cells collided with the Petroff-Hausser slide or with the underside of the cover glass, they usually adhered to it; they spun as they tried to free themselves. Many motile cells lay horizontally, and one end led the other as they swam. Other cells stood vertically, and viewed on end they looked like cocci; they swam sideways (in a direction perpendicular to their long axes) with a vigorous wobble. However, when they adhered to the slide or cover glass, the rod shape was confirmed because the cells tended to assume positions in the same plane as the horizontal surface to which they were stuck. Motility was minimal at $\mathrm{pH}$ extremes (i.e., below $\mathrm{pH} 2.2$ and above $\mathrm{pH} 4.5$ ).

Requirement for oxygen. All of the strains examined were aerobic. Cells were inoculated into $30 \mathrm{ml}$ of molten semisolid ( $0.6 \%$ agar) medium and dispensed into large test tubes (18 by $160 \mathrm{~mm}$ ). Growth occurred only at the surface of the agar and to a depth of $3 \mathrm{~mm}$.

Responses to $\mathbf{p H}$ and temperature. All seven strains grew between $\mathrm{pH} 1.9$ and 5.9 in TS-glucose liquid medium $(100 \mathrm{ml}$ in shaken flasks at $30^{\circ} \mathrm{C}$ ). Slight differences in optimum $\mathrm{pH}$ values (as determined by growth rate) have been observed and reported elsewhere for these organisms (6), but all grew well between $\mathrm{pH} 2.2$ and 5.2. No growth occurred at $\mathrm{pH}$ 6.1. At $\mathrm{pH}$ 1.7 all of the strains lost viability, as determined by plate counts, although a few cells remained viable after 3 days. All seven strains grew slowly below $20^{\circ} \mathrm{C}$ and fastest between 35 and $41^{\circ} \mathrm{C}$, but they did not grow at $47^{\circ} \mathrm{C}$. Strain Lhet2 divided every $6 \mathrm{~h}$ at $25^{\circ} \mathrm{C}$ during the exponential growth phase in TS-glucose liquid medium on the rotary shaker. At $67^{\circ} \mathrm{C}$, five of the seven strains were killed within 2 min (the viable population as determined by plate count decreased from $5 \times 10^{8}$ to $<10^{1}$ cells per ml); strains $\mathrm{m}-3$ and m-5 were killed within $6 \mathrm{~min}$ at this temperature. This degree of heat sensitivity confirmed the observation that endospores are not formed by these organisms.

Response to organic substrates. All seven strains responded similarly with respect to growth on media containing Trypticase soy, glucose, and sodium acetate. Table 2 shows the responses of strain Lhet2 to these compounds. The best cell yield was obtained on media containing $0.01 \%$ Trypticase soy and glucose, whereas $0.05 \%$ Trypticase soy and $0.01 \%$ sodium acetate were inhibitory. Strain $\mathrm{KG}-4 \mathrm{p}$ yielded 2 $\times 10^{8}$ cells per $\mathrm{ml}$ in TS-glucose medium; otherwise this strain responded the same as strain Lhet2. The growth rate of strain Lhet2 in liquid TS-glucose medium on the rotary shaker at $25^{\circ} \mathrm{C}$ was 0.17 division per $\mathrm{h}$ during exponential growth. A glucose concentration above $0.1 \%$ was inhibitory; with $0.2 \%$ glucose, the cells enlarged but did not divide. Growth in cultures was too sparse to permit an accurate measurement of glucose utilization. To demonstrate that strain Lhet2 could consume glucose, cells were harvested from glucose agar and suspended in basal salts medium containing $220 \mu \mathrm{g}$ of glucose per $\mathrm{ml}$ to a concentration of $5 \times 10^{8}$ cells per $\mathrm{ml}$ (plate count). After $38 \mathrm{~h}$ at $35^{\circ} \mathrm{C}$ on the rotary shaker, the population doubled, and $200 \mu \mathrm{g}$ of glucose per ml was consumed. Many organic compounds could replace glucose in the defined medium and could support the growth of all seven strains. These compounds (at concentrations of $0.1 \%$ ) included arabinose, asparagine, 
TABLE 2. Cell yields of strain Lhet2 in different media ${ }^{a}$

\begin{tabular}{cccccccc}
\hline \multirow{2}{*}{$\begin{array}{c}\text { Time of in- } \\
\text { cubation } \\
\text { (days) }\end{array}$} & $\begin{array}{c}\text { No addi- } \\
\text { tion }\end{array}$ & $0.1 \%$ Glucose & $\begin{array}{c}0.1 \% \text { Glucose } \\
+0.01 \% \text { ace- } \\
\text { tate }\end{array}$ & $\begin{array}{c}0.01 \% \text { Tryp- } \\
\text { ticase soy }\end{array}$ & $\begin{array}{c}0.05 \% \text { Tryp- } \\
\text { ticase soy }\end{array}$ & $\begin{array}{c}0.01 \% \text { Trypti- } \\
\text { case soy }+ \\
0.1 \% \text { glucose }\end{array}$ & $\begin{array}{c}0.01 \% \text { Trypti- } \\
\text { case soy }+ \\
0.1 \% \text { glucose }+ \\
0.01 \% \text { acetate }\end{array}$ \\
\hline 0 & $1 \times 10^{5}$ & $1 \times 10^{5}$ & $1 \times 10^{5}$ & $1 \times 10^{5}$ & $1 \times 10^{5}$ & $1 \times 10^{5}$ & $1 \times 10^{5}$ \\
4 & $<10^{6}$ & $1 \times 10^{7}$ & $<10^{6}$ & $3 \times 10^{7}$ & $\sim 10^{6}$ & $1 \times 10^{8}$ & $<10^{6}$ \\
\hline
\end{tabular}

${ }^{a}$ Cultures $(100 \mathrm{ml})$ were grown in 0.5 -liter Erlenmeyer flasks at $28^{\circ} \mathrm{C}$ on the rotary shaker. Assays were performed by using phase-contrast microscopy and a Petroff-Hausser bacterial counting chamber. The assay at zero time (inoculum) was made on the inoculum suspension (from a culture in basal salts medium containing $0.01 \%$ Trypticase soy), correcting for dilution upon addition to the test media. A 100 -ml flask culture was barely turbid to the unaided eye at a cell population of $\sim 10^{7}$ cells per ml. Plate counts confirmed these results with strain Lhet2 and equivalent results with the other six strains.

glycerol, lactose, maltose, mannitol, raffinose, ribose, sodium tartrate, and sucrose. The following compounds did not support growth: cysteine, glycine, sodium glutamate, and sodium lactate. Interestingly, sodium thiosulfate not only did not support growth but also prevented growth in glucose. Growth was measured by plate counts.

DNA analyses. The $\mathrm{G}+\mathrm{C}$ contents of the DNAs of five of the strains were as follows (as determined by the melting point method): strain KG-4p, 68.1 mol\%; strain m-5, 70.0 mol\%; strain 13598het, $70.0 \mathrm{~mol} \%$; strain Dhet1, $69.5 \mathrm{~mol} \%$; and strain Lhet2, $69.8 \mathrm{~mol} \%$. As determined by the buoyant density method, the $\mathrm{G}+\mathrm{C}$ content of strain Lhet2 DNA was $69.4 \mathrm{~mol} \%$ (Mandel, personal communication). The results of a DNA homology study on these organisms have been described previously (6), and it was shown that strains Lhet2, 13598het, $\mathrm{m}-5$, and Dhet1 form a homology group with at least $90 \%$ homology to Lhet2 DNA as reference DNA. Strain KG-4p showed $34 \%$ homology with Lhet2 and thus is somewhat less closely related to strain Lhet2 than the other strains are.

Other traits. All seven strains were inhibited by aureomycin and chloramphenicol, but none was inhibited by erythromycin, neomycin, streptomycin, or penicillin. The sparse growth so characteristic of these bacteria in liquid media was also observed on TS-glucose agar. Thin, translucent growth appeared in 2 to 3 days at $37^{\circ} \mathrm{C}$. If the agar culture was kept for several weeks at $20^{\circ} \mathrm{C}$, the growth became opaque and white or pinkish white. At $37^{\circ} \mathrm{C}$, colonies required 5 to 7 days to attain a diameter of 0.2 to $0.5 \mathrm{~mm}$. Strain Lhet2 was examined for salt tolerance. In liquid TS-glucose medium at $30^{\circ} \mathrm{C}$ on the rotary shaker, the cell yield in medium containing $3 \% \mathrm{NaCl}$ was one-half that obtained under the same conditions in the absence of $\mathrm{NaCl}$, and no growth occurred with $7 \% \mathrm{NaCl}$.
All seven strains were weakly catalase positive and, compared with Pseudomonas and Neisseria species as controls, produced very weak oxidase reactions, if they produced reactions at all.

\section{DISCUSSION}

The acidophilic heterotrophic bacteria described here are widely distributed; they have been isolated directly from (or in $T$. ferrooxidans cultures derived from) copper sulfide ores and pyritic coal and effluents (Table 1) from the East, Midwest, and Rocky Mountain regions of the United States. Similar, perhaps identical bacteria have been found associated with $T$. ferrooxidans in peat from an acidic bog in Soviet Europe (17) and in association with other cultures of $T$. ferrooxidans elsewhere $(8,14)$. Thus, these bacteria represent a common, albeit elusive, group deserving general recognition and a name. The two most striking properties of these bacteria are their high acidophilism and their low tolerance toward organic compounds. They grow at a lower $\mathrm{pH}$ than other nonsporulating obligate heterotrophs (7). However, they cannot be detected with conventional media, even at low pH values. For example, Trypticase soy at a concentration of $0.05 \%$ (far below the $2.7 \%$ recommended by the manufacturer) is inhibitory. The acidophilism of these organisms is shared by some thiobacilli; however, their inability to utilize sulfur or ferrous iron with or without an organic substrate differentiates them from thiobacilli (6). Indeed, not only the lack of DNA homology with $T$. ferrooxidans (6) but also the $\mathrm{G}+\mathrm{C}$ contents of the DNAs of these organisms distinguish them from $T$. ferrooxidans. Thus, strains Lhet2 and 13598het, which were isolated from $T$. ferrooxidans cultures (Table 1), have $\mathrm{G}+\mathrm{C}$ contents of 69.8 and $70.0 \mathrm{~mol} \%$, respectively, whereas $T$. ferrooxidans strains 
have values of 57.2 and $59.5 \mathrm{~mol} \%$, as determined by the melting point method in this study. The $\mathrm{G}+\mathrm{C}$ values of these organisms also differentiate them from Thiobacillus acidophilus $(\mathrm{G}+\mathrm{C}$ content, 62.9 to $63.2 \mathrm{~mol} \%$ [4]). This Thiobacillus species utilizes either sulfur or glucose as a source of energy.

An acid-tolerant heterotroph isolated from coal mine waters was described under the name Flavobacterium acidurans (11). This bacterium is yellow, grows in conventional media $(0.1 \%$ yeast extract plus $0.1 \%$ tryptone [equivalent to Trypticase]), does not grow at $37^{\circ} \mathrm{C}$ or below $\mathrm{pH}$ 4.5 but does grow at $\mathrm{pH} 6.5$, and has a $\mathrm{G}+\mathrm{C}$ content of $66.4 \mathrm{~mol} \%$ in its DNA (11). All of these traits distinguish it from the acidophilic bacteria described here. The flavobacteria are not inhibited by organic compounds, nor are they acidophilic (16).

The flagellation of one of my isolates, strain Lhet2, is similar to that reported for some species of Chromobacterium (15). However, chromobacteria are not acidophilic and grow in conventional peptone digests and extracts. Furthermore, they are characteristically violet or purple. The acidophilic heterotrophs have little in common with pseudomonads, which characteristically are not acidophilic, are tolerant of organic matter, and utilize acetate rather than being inhibited by it (2). Indeed, it appears that no bacteria with the properties of the acidophilic heterotrophs described here have been described and named previously. Therefore, I propose the generic name Acidiphilium gen. nov. (A.ci.di.phi'li.um. M.L. noun acidum an acid; Gr. adj. philus loving; M.L. neut. n. Acidiphilium acid lover) for these organisms. For the name of the type species, Acidiphilium cryptum sp. nov. (cryp'tum. Gr. adj. kryptos hidden; M.L. adj. cryptus hidden). At this time, the genus Acidiphilium contains this one species. Further research may place other species within this genus. Strain Lhet2 is the type strain of A. cryptum and has been deposited with the American Type Culture Collection, under the accession number ATCC 33463. A combined description of the new genus and species follows.

Acidiphilium gen. nov. Gram-negative, mesophilic, aerobic, rod-shaped bacteria. Motile and nonmotile strains occur; motile cells have one polar flagellum or two lateral flagella. Growth occurs in lean organic media between pH 1.9 and 5.9 but not at $\mathrm{pH}$ 6.1. In basal salts medium containing glucose, $0.01 \%$ Trypticase soy stimulates growth, whereas $0.05 \%$ Trypticase soy inhibits growth. Sodium acetate at a concentration of $0.01 \%$ is strongly inhibitory. In defined media (basal salts medium containing a variety of organic compounds), growth is sparse. Although enrichment with $0.01 \%$ Trypticase soy enhances growth, yields of more than $2 \times 10^{8}$ cells per $\mathrm{ml}$ seldom encountered. On agar media at $35^{\circ} \mathrm{C}$, colonies 0.2 to $0.5 \mathrm{~mm}$ in diameter form after 1 week. Growth is slow at temperatures below $20^{\circ} \mathrm{C}$, fastest between 35 and $41^{\circ} \mathrm{C}$, and absent at $47^{\circ} \mathrm{C}$. Endospores are not formed and cells die rapidly at $67^{\circ} \mathrm{C}$. These bacteria are catalase positive, but the oxidase reaction is very weak or absent. Cells in basal salts liquid medium containing glucose measure 0.3 to 0.4 by 0.6 to $0.8 \mu \mathrm{m}$, but cell size and shape are influenced by the kind and concentration of organic substrate and by physical conditions, such as $\mathrm{pH}$. The $\mathrm{G}+\mathrm{C}$ content of the DNA varies between 68 and $70 \mathrm{~mol} \%$. The type species is $A$. cryptum sp. nov., and the type strain of $A$. cryptum is Lhet2 (=ATCC 33463). The descriptions of the type species and the type strain are the same as the description given above for the genus.

\section{ACKNOWLEDGMENTS}

I thank Theodore A. Tarkow and Thomas O. MacAdoo for their help in the construction of the genus and species names, Robin C. Kennedy, who made the electron micrographs, and Susan J. Brown, who prepared the cells for electron microscopy.

\section{REPRINT REQUESTS}

Address reprint requests to: Arthur P. Harrison, Jr., Division of Biological Sciences, University of Missouri, Columbia, MO 65211 .

\section{HTERATURE CITED}

1. Committee on Bacteriological Technique. 1974. Manual for pure culture study of bacteria. Leaflet III. Society of American Microbiologists.

2. Doudoroff, M., and N. J. Palleroni. 1974. Genus Pseudomonas, p. 217-243. In R. E. Buchanan and N. E. Gibbons (ed.), Bergey's manual of determinative bacteriology, 8th ed. The Williams \& Wilkins Co., Baltimore.

3. Dubois, M., K. A. Gilles, J. K. Hamilton, P. A. Rebers, and F. Smith. 1956. Colorimetric method for determination of sugars and related substances. Anal. Chem. 28:350-356.

4. Guay, R., and M. Silver. 1975. Thiobacillus acidophilus sp. nov.; isolation and some physiological characteristics. Can. J. Microbiol. 21:281-288.

5. Harrison, A. P., Jr. 1978. Microbial succession and mineral leaching in an artificial coal spoil. Appl. Environ. Microbiol. 36:861-869.

6. Harrison, A. P., Jr., B. W. Jarvis, and J. J. Johnson. 1980. Heterotrophic bacteria from cultures of autotrophic Thiobacillus ferrooxidans: relationships determined by means of deoxyribonucleic acid homology. $\mathrm{J}$ Bacteriol. 143:448-454.

7. Langworthy, T. A. 1978. Microbial life in extreme $\mathrm{pH}$ values, p. 279-315. In D. J. Kushner (ed.), Microbial life in extreme environments. Academic Press, Inc., New York.

8. Mackintosh, M. E. 1978. Nitrogen fixation by Thiobacil lus ferrooxidans. J. Gen. Microbiol. 105:215-218.

9. Mandel, M., and J. Marmur. 1968. Use of ultraviolet 
absorbance-temperature profile for determining the guanine plus cytosine content of DNA. Methods Enzymol. 12:195-206.

10. Manning, H. L. 1975. New medium for isolating ironoxidizing and heterotrophic acidophilic bacteria from acid mine drainage. Appl. Microbiol. 30:1010-1016.

11. Millar, W. N. 1973. Heterotrophic bacterial population in acid coal mine water: Flavobacterium acidurans sp. n. Int. J. Syst. Bacteriol. 23:142-150.

12. Seidler, R. J., and M. Mandel. 1971. Quantitative aspects of deoxyribonucleic acid renaturation: base composition, state of chromosome replication, and polynucleotide homologies. J. Bacteriol, 106:608-614.

13. Shafia, F., and R. F. Wilkinson, Jr. 1969. Growth of Ferrobacillus ferrooxidans on organic matter. J. Bacteriol. 97:256-260.
14. Silver, M. 1978. Metabolic mechanisms of iron-oxidizing thiobacilli, p. 3-17. In L. E. Murr, A. E. Torma, and J. A. Brierley (ed.), Metallurigical applications of bacterial leaching and related microbiological phenomena. Academic Press, Inc., New York.

15. Sneath, P. H. A. 1974. Genus Chromobacterium, p. 354357. In R. E. Buchanan and N. E. Gibbons (ed.), Bergey's manual of determinative bacteriology, 8 th ed. The Williams \& Wilkins Co., Baltimore.

16. Weeks, O. B. 1974. Genus Flavobacterium, p. 357-364. In R. E. Buchanan and N. E. Gibbons (ed.), Bergey's manual of determinative bacteriology, 8 th ed. The Williams \& Wilkins Co., Baltimore.

17. Zavarazin, G. A. 1972. A heterotrophic satellite of Thiobacillus ferrooxidans. Microbiology (USSR) 41:323324 . 